\title{
Inhibition of cGMP Breakdown Promotes the Induction of Cerebellar Long-Term Depression
}

\author{
Nick A. Hartell \\ Laboratory for Synaptic Function, Frontier Research Program, RIKEN, Wako-shi, Saitama, 351-01, Japan
}

The effects of the nonspecific cyclic nucleotide inhibitors 1-methyl-3-isobutylxanthine (IBMX) and dipyridamole, and the cGMP-specific phosphodiesterase inhibitor Zaprinast were studied on parallel fiber-Purkinje cell synaptic responses in rat cerebellar slices. Bath application of all three compounds, at concentrations shown to inhibit cGMP breakdown, led to stable and robust long-term depression of PF responses. Injections of dipyridamole directly into the Purkinje cell dendrites were similarly effective as bath applications, confirming a postsynaptic site of action. Inhibitors of both protein kinase $G$ and $C$ and also the metabotropic glutamate receptor antagonist MCPG completely prevented the induction of LTD by dipyridamole and Zaprinast. The extent of phosphodiesterase-induced synaptic depression was dependent on the frequency of parallel fiber stimulation, and this form of LTD both occluded and was occluded by LTD induced by pairing parallel and climbing fiber inputs. The degree of LTD induced by IBMX was dosedependent, and also required PKC and PKG activity, but was preceded by a large, transient potentiation of parallel fiber responses occurring by a postsynaptic mechanism independent of cGMP. These data not only confirm that cGMP is capable of inducing cerebellar LTD when paired with paralle fiber stimulation but indicate that cGMP is an endogenous intermediate in this form of synaptic plasticity.

Key words: cGMP; phosphodiesterase inhibitor; cerebellum; Purkinje cell; long-term depression; climbing fiber
Simultaneous, repetitive activation of parallel fibers (PFs), the axons of cerebellar granule cells, and climbing fibers (CFs), axons of inferior olivary neurons, leads to a long-term depression (LTD) of transmission at the PF-Purkinje cell synapse (Ito et al., 1982). Three basic elements are required for LTD. (1) Activation of AMPA receptors (Linden et al., 1993; Hemart et al., 1995), which mediate fast transmission at the PF-Purkinje cell synapse (Konnerth et al., 1990). (2) Activation of metabotropic glutamate receptors (Linden et al., 1991; Alba et al., 1994; Conquet et al., 1994; Hartell, 1994a; Shigemoto et al., 1994), which are likely to be activated at the rates of PF stimulation necessary for LTD induction (Batchelar and Garthwaite, 1993). (3) Calcium influx via voltage-dependent calcium channels (Ross and Werman, 1987; Knöpfel et al., 1990; Sakurai, 1990; Linden and Connor, 1991; Kano et al., 1992; Konnerth et al., 1992). The first two of these requirements are likely to be fulfilled as a result of PF activation. The third is conventionally attributed to the CF input although recent evidence has shown that PF stimulation can also elevate calcium in Purkinje cells (Denk et al., 1995; Eilers et al., 1995; Hartell, in press) and, if sufficiently strong, lead to LTD (Hartell, in press).

The subsequent intracellular events culminating in LTD are not yet fully understood, but evidence is emerging in favor of a chain of events involving nitric oxide (NO), cGMP, and protein kinases C and G (PKC, PKG) (Crepel and Krupa, 1988; Ito and Karachot, 1992; Daniel et al., 1993; Hartell, 1994a,b). In slice preparations,

\footnotetext{
Received Aug. 8, 1995; revised Feb. 1, 1996; accepted Feb. 5, 1996.

This work was supported by the Japanese Science and Technology Agency and the Frontier Research Program, RIKEN. I thank Dr. Masao Ito for support and encouragement, and Drs. D. Okada and R. T. Kado for useful discussions regarding this work.

Correspondence should be addressed to Nick A. Hartell, Department of Pharmaceutical and Biological Sciences, Aston University, Aston Triangle, Birmingham, B4 7ET, UK.

Copyright $\odot 1996$ Society for Neuroscience $0270-6474 / 96 / 162881-10 \$ 05.00 / 0$
}

NO donors, which strongly activate guanylate cyclase to promote the formation of cGMP, facilitate the induction of LTD in most (Crepel and Jaillard, 1990; Shibuki and Okada, 1991; Daniel et al., 1993; Lev-Ram et al., 1995) but not all cases (Glaum et al., 1992), and NO synthase (NOS) inhibitors prevent LTD induction (Crepel and Jaillard, 1990; Shibuki and Okada, 1991; Daniel et al., 1993; Lev-Ram et al., 1995). cGMP itself induces LTD when dialyzed or injected into Purkinje cells (Daniel et al., 1993; IIartell, 1994b), and both this form of LTD and that induced by pairing $P F$ stimulation with CF stimulation are blocked by selective inhibition of PKG (Hartell, 1994b). In culture, however, this $\mathrm{NO} / \mathrm{cGMP} / \mathrm{PKG}$ cascade is apparently not essential for LTD (Linden and Connor, 1992; Linden et al., 1995).

Some authors suggest NO may be a product of CF stimulation (Shibuki and Okada, 1991; Ito and Karachot, 1992; Hartell, 1994b) whereas others implicate the PF input (Lev-Ram et al., 1995). Despite this controversy, there is strong anatomical evidence pointing toward the Purkinje cell as a target for NO. Guanylate cyclase (Ariano et al., 1982), PKG (I ohmann et al., 1981), and its putative substrate G-substrate (Nairn et al., 1985) are all highly expressed in cerebellar Purkinje cells. However, cGMP levels remain conspicuously low in Purkinje cells even after strong pharmacological activation of cerebellar slices (Southam et al., 1992). This absent link in the proposed biochemical chain may be explained by the findings that calcium/calmodulin dependent phosphodicstcrases (PDEs), which brcakdown cGMP, arc abundant in both the soma and dendrites of Purkinje cells (Kincaid et al., 1987; Balaban et al., 1989) and that certain PDE isoforms may be resistant to standard inhibitors, such as 3-isobutyl-methyl xanthene (IBMX) in the presence of calcium (Mayer et al., 1992). Consistent with this is the finding that dendritic injections of cGMP are only capable of inducing LTD in the presence of IBMX (Hartell, 1994b), suggesting that cGMP levels are closely regulated in Purkinje cells. 
The present study was designed to investigate the extent to which endogenous PDEs are active in Purkinje cells and to determine whether modulation of their activity might provide an additional mechanism for the control of synaptic plasticity. The rationale behind using PDE inhibitors to elevate cGMP was to exploit only endogenous cellular pathways for cGMP production to strengthen arguments for a physiological role of the NO/cGMP cascade in cerehellar I.TD. Three different inhibitors were used. Zaprinast, a selective inhibitor of cGMP-specific PDEs (Beavo and Reifsnyder, 1990; Lugnier et al., 1992); dipyridamole, a potent inhibitor of cGMP-specific PDEs $V_{A}$ and $V_{B}$ (Beavo and Reifsnyder, 1990); and IBMX, a nonspecific but widely used PDE inhibitor. Bath applications of all three compounds induced a LTD of PF-EPSP slopes that was primarily postsynaptic in origin and that was blocked by the NOS inhibitor L-nitro-argine (LNARG) and by the specific protein kinase G inhibitor KT5823. This form of LTD was found to be similar to that induced by pairing PF stimulation with either $\mathrm{CF}$ activation/depolarization or injections of cGMP analogs in that it was blocked by the mGluR antagonist (RS)-3,5-methyl-4-carboxyphenylglycine (MCPG) and by the PKC inhibitor chelerythrine (Hartell, 1994b). Zaprinastinduced LTD occluded further depression by conventional pairing of CF and PF stimulation and vice versa. These results not only provide additional evidence that cGMP is capable of inducing LTD by postsynaptic mechanisms in cerebellar Purkinje cells but also that it is likely to be an endogenous intermediate.

\section{MATERIALS AND METHODS}

Sagittal slices ( $400 \mu \mathrm{m}$ thick) of cerebellar vermis were prepared from 6to 8-week-old male Wistar rats as described previously (Hartell, 1994b). Slices were incubated at room temperature in artificial CSF (ACSF) of the following composition (in $\mathrm{mM}$ ): $\mathrm{NaCl} 118, \mathrm{KCl} 4.7, \mathrm{CaCl}_{2} 2, \mathrm{H}_{2} 02.5$, $\mathrm{NaHCO}_{3} 25, \mathrm{KH}_{2} \mathrm{PO}_{4} 1.2, \mathrm{MgSO}_{4} 7, \mathrm{H}_{2} \mathrm{O} 1.2$, glucose 11 , equilibrated with $95 \% \mathrm{O}_{2} / 5 \% \mathrm{CO}_{2}$, pII 7.4. Slices were equilibrated for at least $1 \mathrm{hr}$ before recording.

Two different sets of recording conditions were used. During microelectrode recordings, slices were maintained in an experimental chamber at $32-34^{\circ} \mathrm{C}$, fully submerged and perfused with ACSF at a rate of 2 $\mathrm{ml} / \mathrm{min}$. Dendritic excitatory potentials were recorded using glass micropipettes filled with $3 \mathrm{M} \mathrm{KCl}$. When phosphodiesterase or protein kinase inhibitors were included in the filling solution, they were (with the exception of chelerythrine, which is water-soluble) initially dissolved in DMSO. PF and CF responses were evoked with bipolar platinum-iridium electrodes positioned close to the pia in the molecular layer and on the white matter, respectively. The recording electrode was placed approximately midway in the molecular layer, to ensure that the electrode was placed more distally in the dendrite. Spontaneous sodium spikes of somatic origin were always less than $2 \mathrm{mV}$ in amplitude, confirming that recordings were made primarily from more distal dendrites (see Hartell, 1994b).

$\mathrm{CF}$ responses were recorded at intervals throughout the experiments to confirm that any changes in synaptic strength were confined to the PF Purkinje cell synapse. Data were excluded if $\mathrm{CF}$ responses changed significantly in amplitude. PF responses were evoked continuously at a rate of $1 \mathrm{~Hz}$. Five consecutive sweeps of data were sampled at $1 \mathrm{~min}$ intervals and stored on computer for off-line analysis. Before injection or bath application of drugs, a 15 min control period was allowed of which the first 5 min were usually discarded because PF responses were initially somewhat variable. Changes in synaptic strength were monitored by measuring the initial slope of the PF-induced EPSPs and expressing these changes as percentages of control data.

For Zaprinast experiments, whole-cell somatic patch recordings, in current clamp mode, were made from $200-\mu$ m-thick slices, fully submerged and maintained in picrotoxin containing ACSF $(20 \mu \mathrm{M})$ at room temperature. A potassium based internal tilling solution was used comprising (in $\mathrm{mM}$ ): $\mathrm{KCl} 132, \mathrm{NaCl} 8, \mathrm{MgCl}_{2}$ 2, EGTA 0.5, HEPES 30 , $\mathrm{Na}_{2} \mathrm{ATP} 4$, GTP 0.3, adjusted to $\mathrm{pH} 7.3$. In these experiments, two separate $\mathrm{PF}$ input pathways were activated alternately using patch electrodes filled with ACSF. Series resistance was monitored continuously and data were discarded if a significant change was observed over the course of the experiment. In all experiments, measurements of cell input resistance were made continuously to ensure that any changes in response characteristics were not attributable to changes in cell or recording conditions. Data were excluded if the input resistance changed significantly over the course of the experiment.

Drug injections from micropipettes were made by applying a positive pressure of between 10 and 15 psi using a syringe. Injection was initially accompanied by a 3-5 $\mathrm{M} \Omega$ decrease in electrode resistance that recovered slowly over 5-10 min as the pressure declined. Data were discarded if there was any significant change in either input resistance or membrane potential. Dipyridamole, Zaprinast and IBMX (Sigma, St. Louis, MO) and KT5823 (Kyowa Medex Co. Ltd.) were dissolved in DMSO before dissolving in $3 \mathrm{M} \mathrm{KCl}$ recording solution. Control injections of similar concentrations of DMSO in $\mathrm{KCl}$ or $\mathrm{KCl}$ alone did not produce any effect. Chelerythrine was obtained from Alamone Labs.

With the exception of LNARG (Sigma), MCPG, and 8-cyclopentyl-1,3dipropylxanthene (DPCPX, Tocris Neuramin), compounds applied in the perfusate were dissolved in DMSO. Final concentrations of DMSO did not exceed $0.05 \%$. DPCPX was dissolved in ethanol and added to the perfusate at least $10 \mathrm{~min}$ before starting recordings. Where used, LNARG and KT5823 were included in the perfusate throughout the experiments, including cutting and incubation. Other compounds were bath applied for $10 \mathrm{~min}$ after suitable control periods unless otherwise mentioned in the text. MCPG $(500 \mu \mathrm{M})$ was applied for $15 \mathrm{~min}$ before and during dipyridamole application and maintained an additional 2-5 min after washout onset.

\section{RESULTS}

Within 2-3 min of a 10 min bath application of $20 \mu \mathrm{M}$ dipyridamole, a small, 2-3 mV depolarization occurred in six of the seven cells studied, which gradually returned to preapplication levels within 5-20 min of the onset of washout. Without exception, the initial slopes of the rising phase of PF EPSPs (EPSP slopes) were markedly reduced within 1-2 min of dipyridamole application (see Fig. $1 A$ for an example and Fig. $3 A$ for the pooled data; solid circles) and reached a minimum value of $38 \pm 6.7 \%$ (mean $\pm \mathrm{SE}$, $n=7$ ) of the preapplication control within $12 \mathrm{~min}$. Any recovery of EPSP slopes generally stabilized within $20 \mathrm{~min}$; however, responses remained depressed reaching an average level of only 54 $\pm 9.0 \%$ of control values even $60 \mathrm{~min}$ after washout and remained significantly different from control valucs (paired $t$ test, $p<$ $0.005)$. Complete recovery was never observed. In contrast, $\mathrm{CF}$ responses (see Fig. $1 A$ ) remained constant in size and appearance before, during and after application. Whereas dipyridamole caused no long-term effect on membrane resistance, some decrease was generally observed during application. Full recovery after washout was a criterion for inclusion of the data in the analysis.

Bath applications of $5 \mu \mathrm{M}$ Zaprinast, a more selective inhibitor of cGMP-specific phosphodiesterases (Beavo and Reifsnyder, 1990; Lugnier et al., 1992), produced a more uniphasic profile of depression of PF-EPSP slopes (see Fig. $1 B$ for an example and Fig. $3 B$ for pooled data) in cells recorded under whole-cell patch conditions and in the presence of picrotoxin. Depression occurred within 1-2 min of application and was maximal during or shortly after the application period. Although some recovery occurred after washout this was clearly less marked than that observed after dipyridamole treatment and responses remained significantly depressed relative to control values even $60 \mathrm{~min}$ after application (40 $\pm 5.7 \%$ of control values, $p<0.01$, paired $t$ test, $p<0.01, n=5$ ). Zaprinast also induced a clear $4-5 \mathrm{mV}$ depolarization that was, in three out of five cases, succeeded by a small 2-3 mV hyperpolarization (Fig. $2 A$ ) within a few minutes of washout. The onset of the depolarization coincided with a substantial decrease in membrane resistance in all cells (Fig. $2 B$ ). This also recovered after 
A

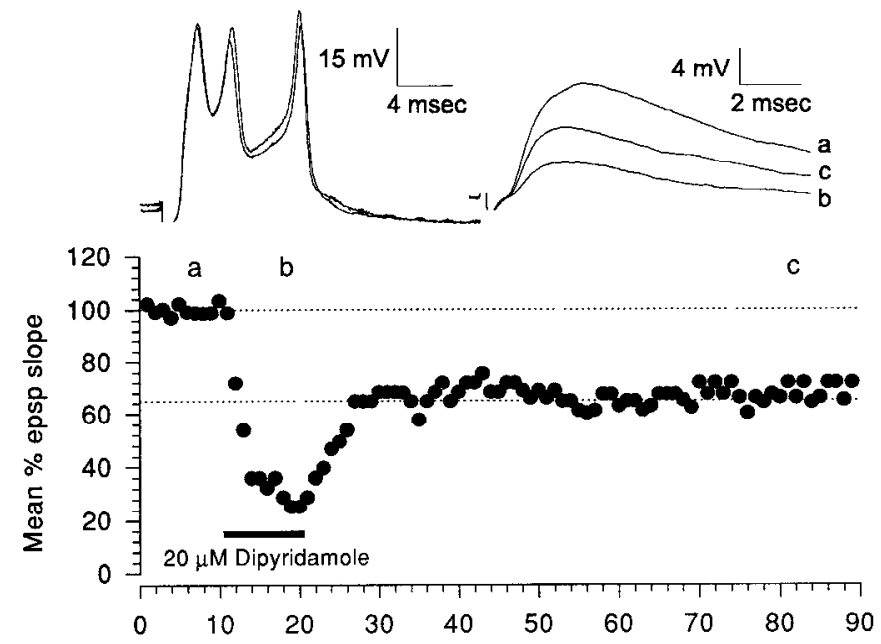

B

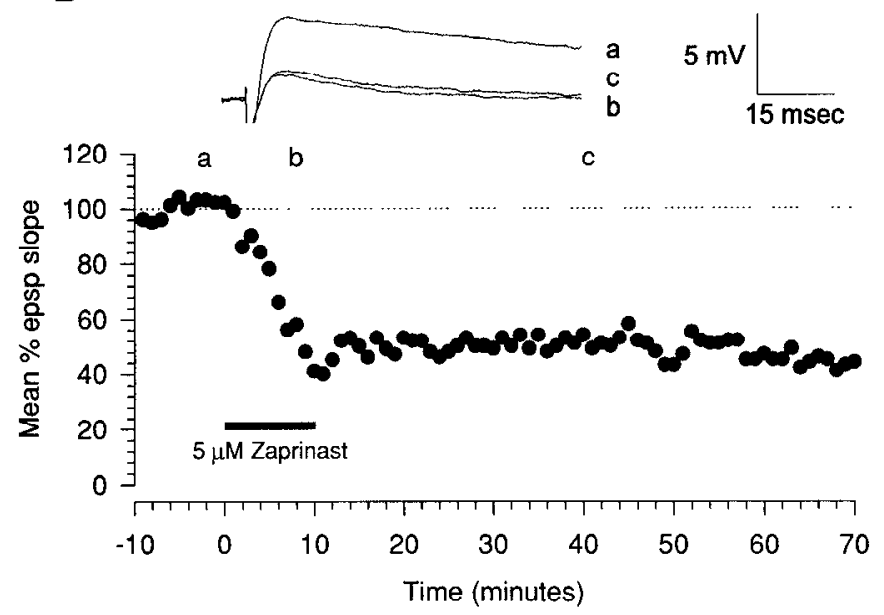

Figure 1. PDE-inhibitor-induced LTD. $A$, Ten minute bath application of $20 \mu \mathrm{M}$ dipyridamole induced two distinct phases of depression of PFmediated EPSP slopes. The horizontal bar marks the time of application. Illustrated above are representative CF responses taken at the heginning and end of the experiment (left) and averages of five successive PF traces (right) collected at the times marked on the graph. $B$, The effects of a 10 min bath application of $5 \mu \mathrm{M}$ Zaprinast on PF responses.

washout but at a slightly slower rate than that of the membrane potential.

Both Zaprinast and dipyridamole additionally induced significant changes in the time course of PF-EPSPs (see raw data in Fig. $1 A, B)$. These effects were more evident under Zaprinast treatment because these experiments were performed in the presence of the $\mathrm{GABA}_{\mathrm{A}}$ receptor antagonist picrotoxin, which significantly prolongs the duration of PF-EPSPs. To quantify these changes, PF-EPSPs were fitted with double exponential curves and the time constant for the falling phase $\left(\tau_{2}\right)$ and the time to peak were calculated. Figure $2 C-E$ illustrates changes in these parameters during Zaprinast application for the same cell shown above and in Figure $1 B$. Before drug application, the absolute value of $\tau_{2}$ was highly variable and tended to decline somewhat during the control period. The mean value of $\tau_{2} 5 \mathrm{~min}$ before drug application was $159 \pm 19 \mathrm{msec}(n=8)$. During Zaprinast application $\tau_{2}$ decreased dramatically to a value of $23 \pm 3 \mathrm{msec}$ ( $15 \%$ of control) within 10 min of application (see Fig. $2 C$ for an example). Although some
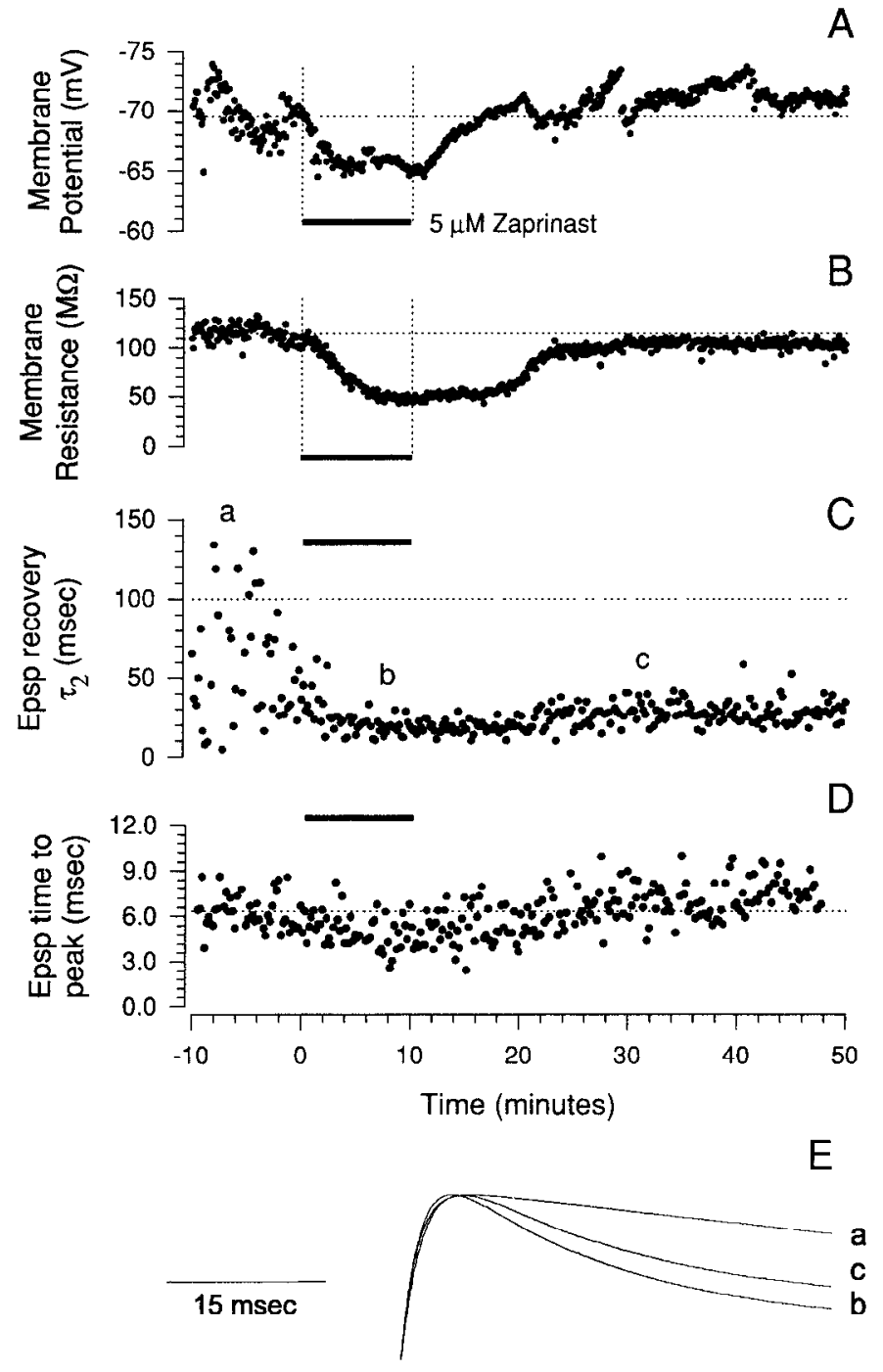

Figure 2. Effects of Zaprinast on membrane properties and EPSP kinetics. A representative example of the effects of Zaprinast on membrane potential $(A)$, membrane resistance $(B)$, EPSP decay time constant $\left(\tau_{2}, C\right)$, and EPSP time-to-peak $(D)$. Five responses taken at times $a-c$ in Figure $2 C$ were averaged and fitted with a doubleexponential curve. The curves are shown in $E$, normalized to the peak amplitude of the control response $a$.

recovery was observed during washout in all cells, complete recovery was never seen and reached a mean value $30 \mathrm{~min}$ after washout of only $35 \%$ of control $(56 \pm 17 \mathrm{msec})$. The time to peak of the EPSP also altered during Zaprinast treatment, undergoing a decrease of between $1-3 \mathrm{msec}(n=8)$. This was transient and recovered fully to control levels shortly after washout (Fig. $2 D$ ). Figure $2 E$ provides representative examples of the fitted, double exponential curves taken at the times indicated and normalized to the peak amplitude of the response taken at time $a$ in Figure $2 C$.

To determine whether any or all of these effects were mediated via the proposed $\mathrm{NO} / \mathrm{cGMP} / \mathrm{PKG}$ cascade, NO synthase was blocked with LNARG and PKG was blocked with KT5823, which is, at this concentration, a highly specific inhibitor of the proposed target for cGMP, protein kinase G (see Nakanishi, 1989; Ito and Karachot, 1992). Preincubation of slices with $10 \mu \mathrm{M}$ LNARG reduced both the short and long-term effects of dipyridamole on PF-EPSP slopes (Fig. 3A, open squares). The mean peak reduc- 
A

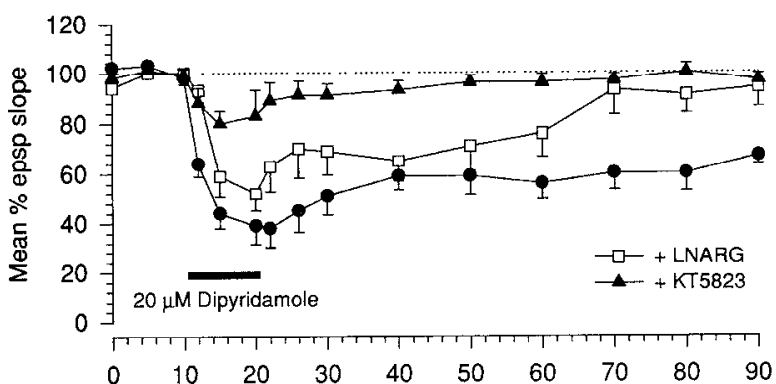

B

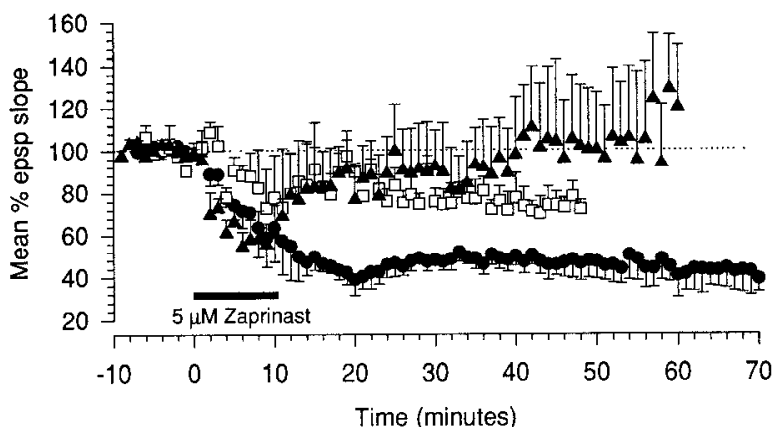

C

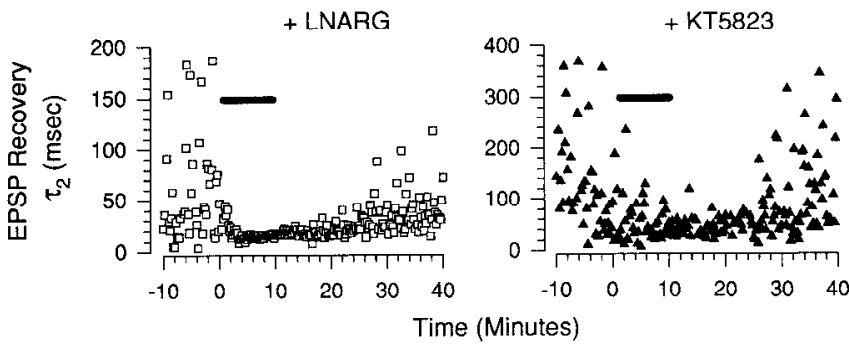

Figure 3. Effects of NOS and PKG inhibitors. $A$, Combined data illustrating the effects of application of $10 \mu \mathrm{M}$ dipyridamole alone $(n=7$; circles $)$, and in the presence of $10 \mu \mathrm{M} \mathrm{LNARG}(n=5 ;$ squares $)$ and $90 \mathrm{nM}$ KT5823 $(n=5$; triangles $)$. Means and SEs are shown. LNARG and KT5823 were included in the perfusate throughout the experiments. $B$, Similar experiments pcrformcd using Zaprinast. LNARG and KT5823 were used at concentrations of 50 and $0.2 \mu \mathrm{M}$, respectively. $C$, Single-cell examples of the effects of Zaprinast on the decay time constant of EPSPs recorded in the presence of $50 \mu \mathrm{M}$ LNARG (left) and $0.2 \mu \mathrm{M}$ KT5823 $($ right $)$.

tion in PF mediated EPSP slope in the presence of this NOS inhibitor was $56 \pm 6.9 \%$ of control $(n=5)$, compared with $38 \pm$ $6.7 \%$ in the absence of LNARG, and 60 min after washout $91 \pm$ $5.5 \%$ (compared with $54 \pm 9.0 \%$ ). Similarly, KT5823 completely inhibited the induction of LTD by dipyridamole application but only partially diminished the shorter term decrease in EPSP slope prominent during dipyridamole application (Fig. $3 A$, solid triangles $)$. Both LNARG $(50 \mu \mathrm{M}, n=5, p<0.05$, open squares $)$ and KT5823 $(0.2 \mu \mathrm{M} n=6, p<0.01$, open squares $)$ also significantly reduced the long-term depression of PF-EPSPs slopes induced by Zaprinast (Mann-Whitney $U$ test; Fig. 3B). The short-term effects of Zaprinast were only partially attenuated even at these higher concentrations of $\mathrm{NO}$ and $\mathrm{PKG}$ inhibitors, suggesting that any remaining effect occurred through mechanisms independent of the $\mathrm{NO} / \mathrm{cGMP} / \mathrm{PKG}$ cascade.

Both LNARG and K' 15823 substantially reduced the long-term effects of Zaprinast on the decay time constant of PF-EPSPs $\left(\tau_{2}\right.$,
Fig. $3 C$ ), indicating that this change in EPSP duration is also mediated to some extent by NO/cGMP/PKG. In the presence of KT5823, mean control values of $\tau_{2}$ were, on average, slightly higher than those in naive slices ( $177 \pm 40 \mathrm{msec}, n=5$ ) and were depressed to $33 \%$ of control values $(59 \pm 16 \mathrm{msec})$ within $10 \mathrm{~min}$ of Zaprinast application and recovered to a level of $67 \%$ of control $(118 \pm 25 \mathrm{msec})$ after $40 \mathrm{~min}$. For LNARG, these values of $\tau_{2}$ were $124 \pm 22 \mathrm{msec}(n=5), 20 \pm 1 \mathrm{msec}(16 \%$ of control) and $69 \pm 14 \mathrm{msec}(56 \%$ of control), respectively. Neither compound had any significant effects on Zaprinast-induced depolarization, decline of membrane resistance, or time to peak, suggesting that these processes were not mediated directly through cGMP.

To determine whether the effects of phosphodiesterase inhibitors were mediated through postsynaptic events $100 \mu \mathrm{M}$ dipyridamole, dissolved in DMSO, was added to the micropipette filling solution $(3 \mathrm{M} \mathrm{KCl})$ in a total of seven cells. After a 10 min control period, a small positive pressure was applied to the pipette. Figure $4 A$ illustrates for a single cell that a clear depression in PF responses occurred progressively after injection and was maintained for the duration of the recordings. Of the seven cells injected, five underwent a significant reduction in PF responses. The overall level of depression after 60 min for these five cells was statistically indistinguishable from that induced hy hath application. Two other cells, not illustrated, showed an equally clear cut potentiation of responses. No obvious cell depolarization accompanied the injections in any of the cases nor was there any evidence of a decrease in the time to peak of EPSPs after injection.

Further evidence that dipyridamole has postsynaptic actions is shown in Figure $1 B$. Here, the effects of bath application of dipyridamole are contrasted with similar applications to cells recorded with either $5 \mu \mathrm{M}$ KT5823 (dissolved in DMSO) or $10 \mu \mathrm{M}$ chelerythrine (a highly specific PKC inhibitor; Herbert et al., 1990) included in the micropipette filling solution and ejected with a small positive pressure injection before and during the control period. Both kinase inhibitors were effective in blocking the effects of dipyridamole such that both the long and short-term effects of dipyridamole were largely attenuated. Neither compounds appeared to have any obvious effect on EPSPs before dipyridamole application as indicated by the stable control period. The inclusion of $2 \mu \mathrm{M}$ chelerythrine or KT5823 in the patch pipette blocked Zaprinast-induced LTD of PF-EPSP slopes (Fig. $4 C)$ and strongly reduced the long-term effects on the recovery phase of the EPSPs [67\% and 93\% of control values $(n=4)$, respectively] after $40 \mathrm{~min}$. Chelerythrine had little or no effect on either the short-term decrease in $\tau_{2}(19 \%$ and of control) or on the reduction in time to peak. Similarly, postsynaptic KT5823 had no effect on the short-term the reduction in time to peak but did partially reduce the short-term decrease in $\tau_{2}$ (52\% of control).

In the hippocampus, Zaprinast or NO donor induced depression of field excitatory potentials, elicited by stimulation of the Schaffer collateral-commissural pathway, is mediated through adenosine-A1 receptors (Broome et al., 1994). The specific adenosine-A1 receptor antagonist DPCPX (Bruns et al., 1987) was used to determine whether any of the effects of Zaprinast on PF-Purkinje cell transmission were mediated through this receptor subtype; $100 \mathrm{~nm} \mathrm{DPCPX} \mathrm{induced} \mathrm{large,} \mathrm{sustained} \mathrm{increases} \mathrm{in}$ PF-EPSP initial slopes and amplitudes rapidly after application (data not shown), indicating a basal level of adenosine activity. Because large PF EPSPs can induce sufficient calcium influx to induce LTD through PF stimulation alone (Eilers et al., 1993; 

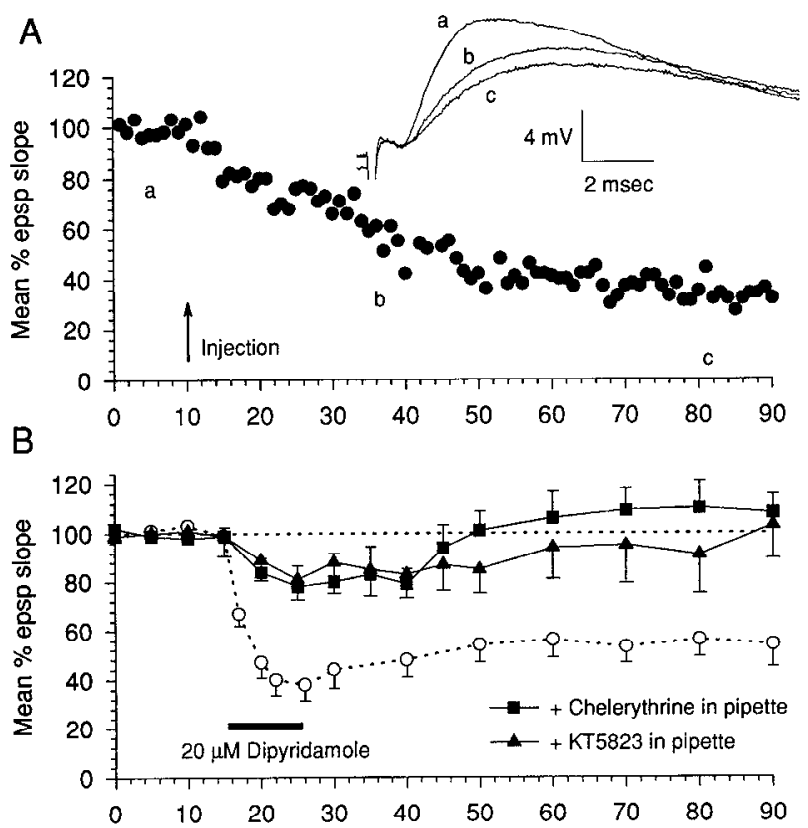

C

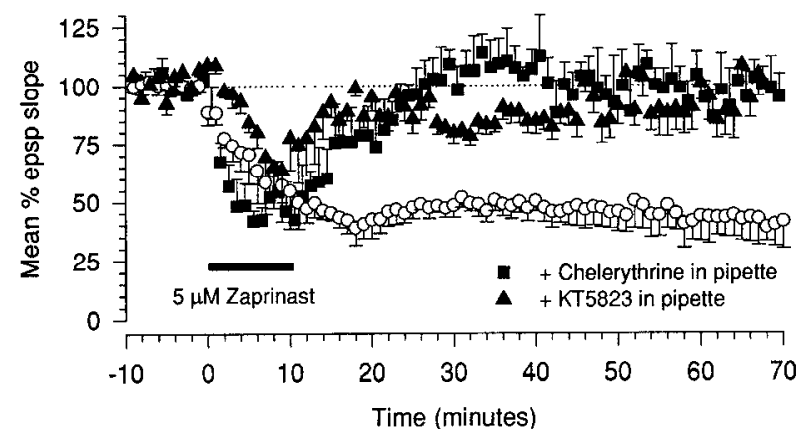

Figure 4. Postsynaptic actions of dipyridamole. $A$, Pressure injection of $100 \mu \mathrm{M}$ dipyridamole into Purkinje cell dendrites. A typical example is shown with averages of five successive, representative traces taken at times $a-c$ illustrated above. $B$, The effects of bath application of dipyridamole on $\mathrm{PF}$ responses are compared for data obtained using microelectrodes containing just $3 \mathrm{M} \mathrm{KCl}$ (open circles; taken from Fig. $1 B$ ) with data obtained with either $10 \mu \mathrm{M}$ chelerythrine (solid squares; $n=4$ ) or $5 \mu \mathrm{M}$ KT5823 (solid triangles; $n=7$ ) included in the pipettes. Fifty minutes aftcr application, data obtained with the protein kinase inhibitors in the pipettes were significantly different from controls (Mann-Whitney $U$ test, $p<$ 0.05). C, A similar comparison was made for the effects of Zaprinast on PF-EPSP slopes between responses recorded with $5 \mu \mathrm{M}$ chelerythrine (solid squares; $n=5$ ) and $5 \mu \mathrm{M} \mathrm{KT5823} \mathrm{(} n=3$; solid triangles) included in patch pipettes and those obtained using standard internal solutions (open circles; $n=5$ ). Data from these two groups remained significantly different for as long as could be recorded (Mann-Whitney $U$ test, $p<0.05$ ).

Hartell, in press), DPCPX was applied to slices before recording and stimulus strengths were carefully adjusted at the outset of experiments to minimize the likelihood of calcium influx. In the presence of 100 nм DPCPX, Zaprinast induced PF-EPSP slupe depression that was indistinguishable from that observed in untreated slices (compare Fig. $5 A$ with $3 B$ ). Furthermore, blockade of adenosine- 1 receptors did not alter any of the changes in either membrane potential (data not shown), membrane resistance (Fig. $5 B$ ), EPSP time to peak or $\tau_{2}$ (Fig. $5 B, C$ ) associated with Zaprinast application. DPCPX did, however, permit a complete recovery of $\tau_{2}$ to control levels after washout of Zaprinast (Fig. 5B) even though EPSP slopes remained depressed. These results
A

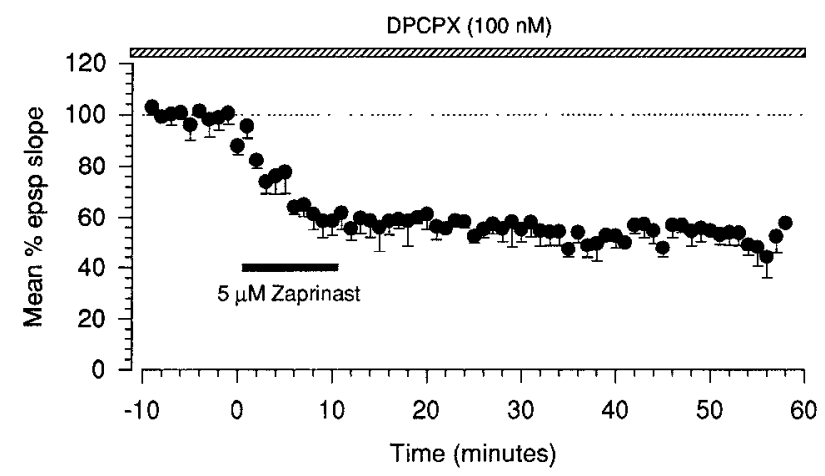

B

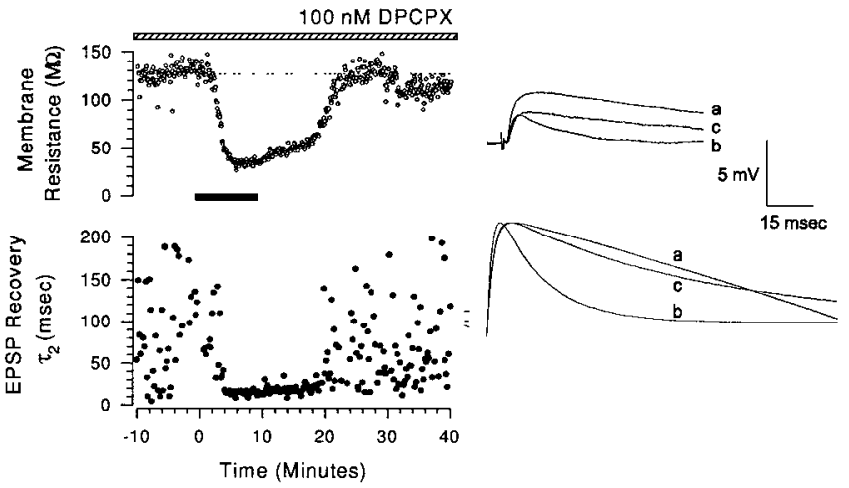

Figure 5. Actions of the adenosine- 1 receptor inhibitor DPCPX. $A$, The effects of Zaprinast on PF-EPSP slopes $(A ; n=5)$ and membrane resistance and EPSP decay time constant $(B)$ in the presence of $100 \mathrm{nM}$ DPCPX $(n=5)$. Data are presented as in Figure $3, B$ and $C$. $C$, Five consecutive EPSPs were sampled at the times indicated in Figure $4 B$ and illustrated in the top panel of $C$. Below are the fitted curves to these responses, normalized to the control response taken at time $a$.

indicate that the long-term reduction in EPSP decay time constant after PDE inhibitor applications is not merely a consequence of the decline in EPSP slopes but is an independent process that requires activation of the NO/cGMP/PKG cascade for its induction and adenosine-A1 receptor activity for its expression.

Injections of cGMP into Purkinje cell dendrites can induce LTD and the extent of depression is increased when associated with PF stimulation (Hartell, 1994b). If the long-term effects of dipyridamole and Zaprinast are also mediated through postsynaptic effects of cGMP, the level of depression of EPSP slopes should also be influenced by the level of PF stimulation. Cessation of PF stimulation during dipyridamole application and for an additional $5 \mathrm{~min}$ of washout led to a comparatively smaller degree of depression (Fig. 6A, diamonds). If PF stimulation was halted for up to $15 \mathrm{~min}$ after washout, responses were initially potentiated but then gradually became depressed but to an extent significantly less than that observed with concurrent PF stimulation during application. The initial potentiation was smaller but similar in time course to that observed in control experiments where PF stimulation was simply halted for $10 \mathrm{~min}$ after a suitable control period.

The dependence on PF input is further highlighted in Figure $6 B$. In a group of five cells, under whole-cell current clamp, two separate inputs to a single Purkinje cell were activated alternately at $1 \mathrm{~Hz}$ (open circles) and $0.2 \mathrm{~Hz}$ (solid circles), respectively. After bath application of $5 \mu \mathrm{M}$ Zaprinast, depression was induced more 
A

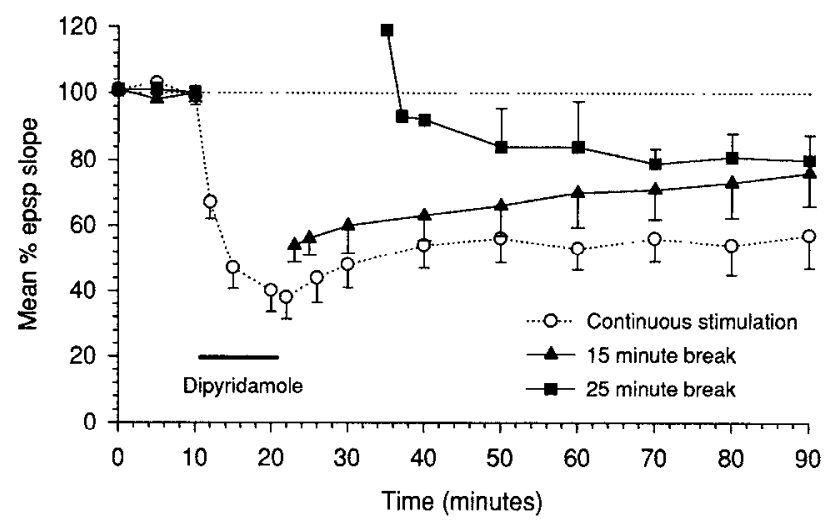

B

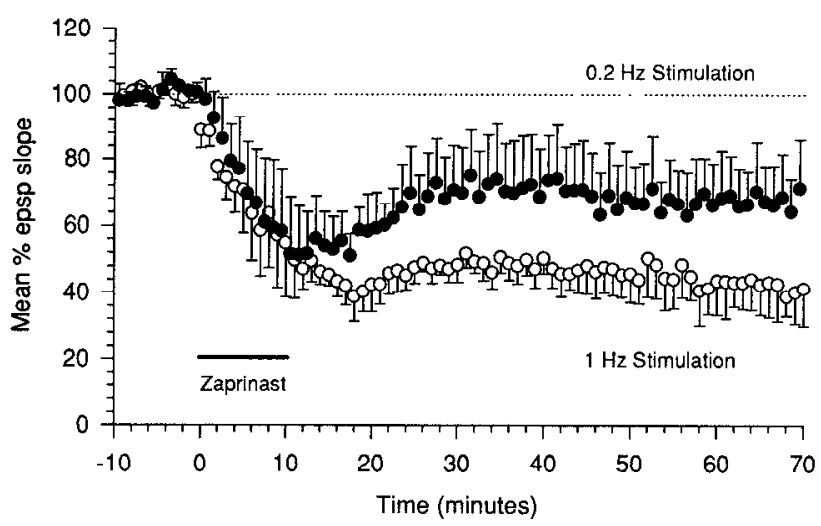

Figure 6. Dependence on PF stimulation. $A$, The effect of dipyridamole application in the presence (open circles) and absence of PF stimulation are compared. PF stimulation was halted during dipyridamole application and for a further period of 5 min (solid squares; $n=7$ ) or for 15 min after washout onset (solid squares; $n=4$ ). $B$, The effects of Zaprinast were compared on separate pathways to the same cell stimulated alternately at rates of $1 \mathrm{~Hz}$ (open circles) and $0.2 \mathrm{~Hz}$ (solid circles). A significantly larger depression was observed within $10 \mathrm{~min}$ of washout in the pathway stimulated at the higher rate (Wilcoxon paired test, $p<0.01$ ).

strongly in the pathway that was activated at the higher frequency. Fifty minutes after application, responses were $43.8 \pm 7.7 \%$ of control values at $1 \mathrm{~Hz}$ stimulation compared with $75.0 \pm 13.2 \%$ control at $0.2 \mathrm{~Hz}(n=5)$. The similarity between the LTD inducing abilities of Zaprinast and dipyridamole lends support to the argument that, in both cases, these changes are taking place via changes in cGMP levels.

Given that activation of mGluRs is essential for cGMP-induced LTD (Hartell, 1994a), and that this subtype of glutamate receptor is more adequately activated at higher frequencies of PF stimulation (Batchelar and Garthwaite, 1994) the effects of the specific, competitive mGluR antagonist MCPG were examined on PDEinhibitor-induced LTD. Previous incubation of slices for $15 \mathrm{~min}$ with $500 \mu \mathrm{M}$ MCPG prevented the induction of LTD by bath applications of either dipyridamole (Fig. $7 A, n=5$ ) or Zaprinast (Fig. $7 B, n=5$ ) and reduced the long-term decline of $\tau_{2}$ associated with PDE-inhibitor application (data not shown). MCPG had little effect on the short-term depression of EPSP slopes, $\tau_{2}$, time to peak of EPSPs or on membrane potential and conductance. In agreement with a previous study (Hartell, 1994a), MCPG itself did not have any apparent effect on membrane resistance or potential, or on either PF or CF responses.
A

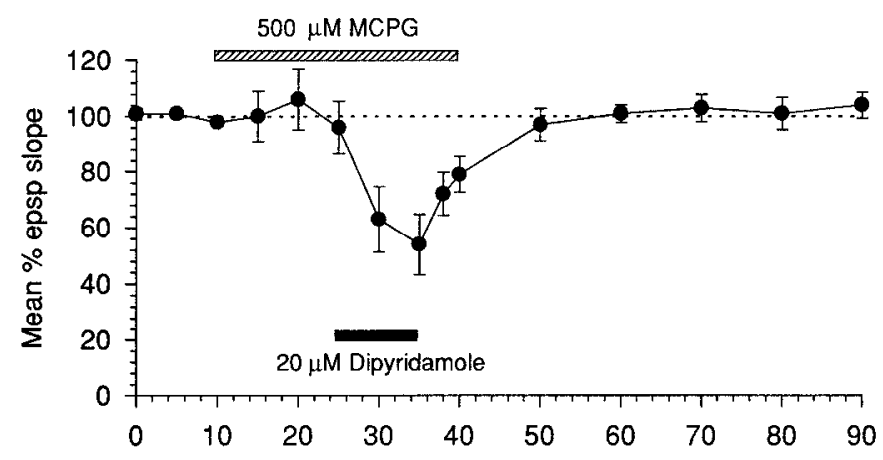

B

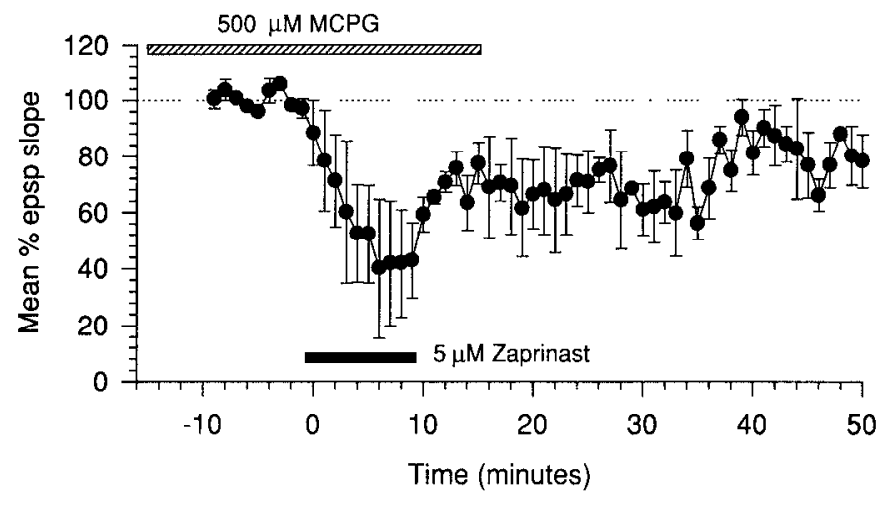

Figure 7. Requirement for mGluR activation. Data are illustrated as in Figure 1. Five hundred micromolars MCPG was hath-applied for $1.5 \mathrm{~min}$ before application of $20 \mu \mathrm{M}$ dipyridamole application $(n=5)$.

To determine whether the LTD induced by inhibition of phosphodiesterases occurred through processes common to LTD induced by conventional pairing of PF and $\mathrm{CF}$ inputs (conjunctive stimulation), occlusion experiments were performed. Figure $8 \mathrm{~A}$ illustrates that after the induction of LTD in only one of two PF inputs to a single Purkinje cell (solid circles), further depression to the same pathway was not observed after bath application of Zaprinast. Depression was observed, however, in the alternate input pathway (open circles). Similarly, after induction of LTD by pairing PF stimulation at $1 \mathrm{~Hz}$ with Zaprinast application, additional LTD was not produced using conjunctive stimulation of PF and CF inputs (Fig. $8 B$ ). Similar results were obtained in each case on two further occasions.

Figure $9 A$ illustrates the effects of $10 \mathrm{~min}$ bath applications of IBMX on PF responses. At concentrations of both 0.1 and $1 \mathrm{~mm}$, IBMX produced a dramatic potentiation of EPSP slopes during application reaching peak levels of $183 \pm 28 \%(n=4)$ and $149 \pm$ $16 \%(n=4)$ of control values, respectively. In both cases, during washout, this potentiation slowly declined to levels below control values and at $60 \mathrm{~min}$ after washout, average levels were $82 \pm 2 \%$ and $59 \pm 8 \%$ of control, respectively $(n=4)$. The depression persisting $60 \mathrm{~min}$ after washout was, in both cases, significantly different from control values (paired $t$ test, $p<0.01$ ). No obvious change in membrane properties were associated with either of these changes in EPSP slope. Figure $9 B$ provides a comparison of the level of depression induced by each of the four methods of LTD induction used in this study and indicates that the levels of induced depression, 50 or $60 \mathrm{~min}$ after treatment, were com- 

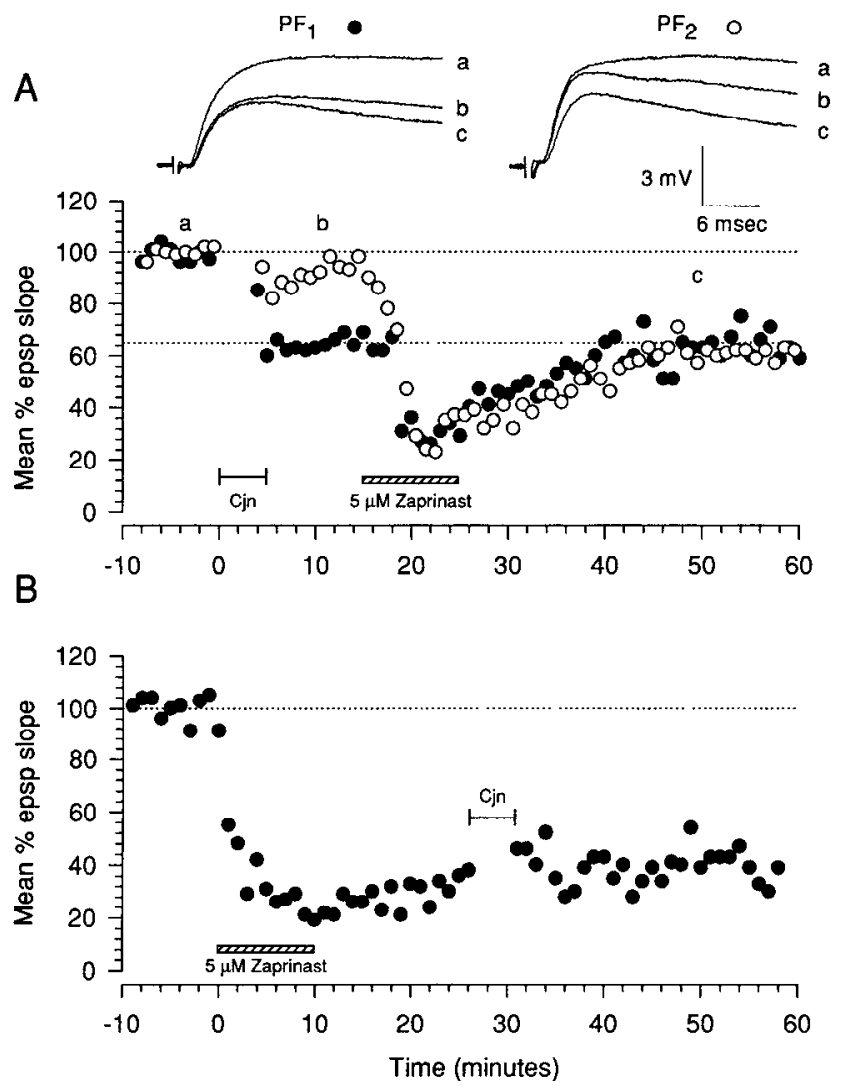

Figure 8. Occlusion of phosphodiesterase-induced LTD. $A$, Two separate $\mathrm{PF}$ inputs to the same cell were activated altcrnatcly at $1 \mathrm{~Hz}$. Aftcr a suitable control period, one input was activated 300 times together with PF stimulation and subsequently underwent depression (solid circles). The other input pathway remained unaffected (open circles). After $10 \mathrm{~min}$, Zaprinast was bath-applied. Shown above are representative PF responses taken at the times indicated on the graph. $B$, Induction of LTD by bath application of Zaprinast prevented further depression by conventional pairing of $\mathrm{CF}$ and $\mathrm{PF}$ inputs.

parable for all three phosphodiesterase inhibitors and for LTD induced by conjunctive stimulation.

Intradendritic injection of IBMX (1 mM dissolved in DMSO and added to $3 \mathrm{M} \mathrm{KCl}$ ) produced a rapid, long lasting potentiation of EPSP slopes ( $n=4$, Fig. $10 A$ ). No sign of a later depression was observed. Injection of the vehicle alone had no effect (open circles, $n=5$ ). Because the LTD induced by bath application of IBMX occurred only after washout, in three experiments the duration of bath application of $1 \mathrm{mM}$ IBMX was prolonged by $15 \mathrm{~min}$ to determine whether the continuous potentiation observed after injection resulted merely from the continued presence of IBMX in the cell. As is clear from the examples shown in Figure $10 B$, extending the duration of IBMX application simply prolonged the duration of the potentiation but did not affect the final extent of the LTD occurring after washout.

To ascertain which part of the response profile may have been mediated by cGMP elevation, $1 \mathrm{mM}$ IBMX was bath applied in the presence of $90 \mathrm{~nm} \mathrm{KT5823} \mathrm{(Fig.} \mathrm{10C,} \mathrm{solid} \mathrm{squares).} \mathrm{In} \mathrm{this} \mathrm{case,}$ a much larger initial potentiation was observed (peak $265 \pm 39 \%$, $n=4)$ that declined only partially (192 $\pm 35 \%$ after $60 \mathrm{~min}$ washout). In five cases, inclusion of chelerythrine into the microelectrode, to a concentration of $10 \mu \mathrm{M}$, prevented the induction of LTD but, unlike KT5823, it did not affect the initial level of potentiation induced by $1 \mathrm{mM}$ IBMX.
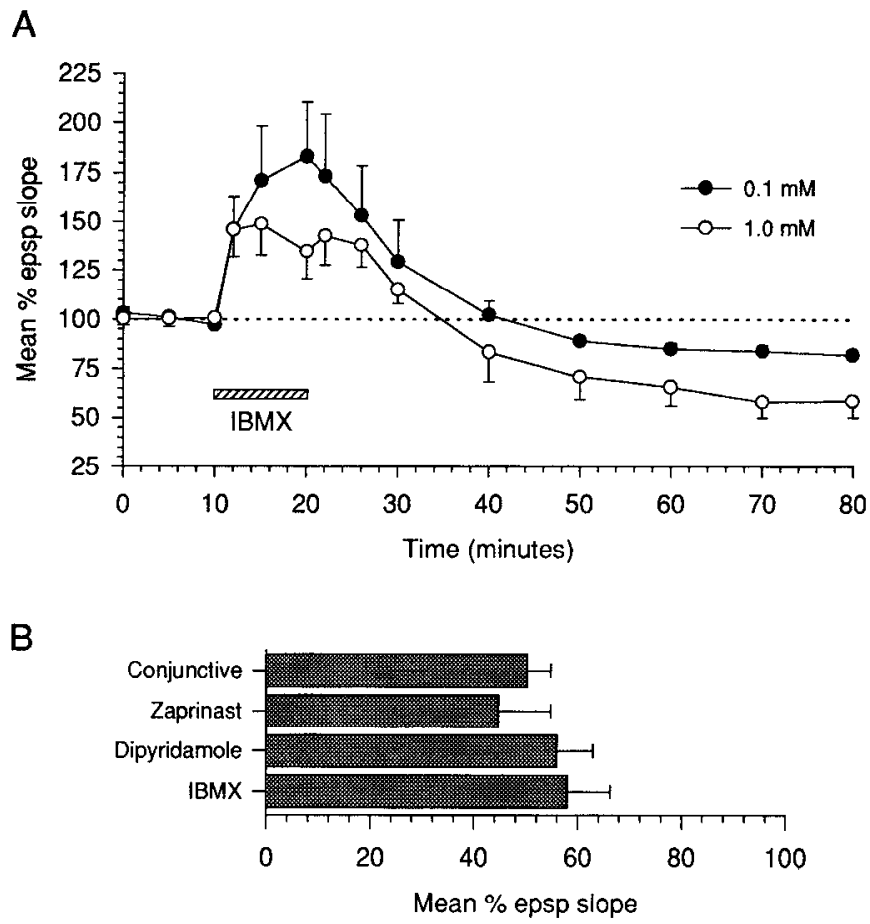

Figure 9. Bath application of IBMX $A$, Effect of 10 min bath application of 0.1 (solid circles) and $1.0 \mathrm{mM}$ (open circles) IBMX. Mean PF-induced EPSP slopes, expressed as a percentage of preapplication control responses, are plotted against time. SEs are shown. $B$, A comparison of the extent of depression caused by bath applications of IBMX, dipyridamole, and Zaprinast, and by conjunctive stimulation. Data were obtained at either 50 or 60 min after the end of cach respective protocol. Means and SEs are shown.

\section{DISCUSSION}

\section{Mechanisms and properties of phosphodiesterase inhibitor-induced depression}

The short-term effects of both dipyridamole and Zaprinast on membrane potential, membrane resistance and the time to peak of PF-Purkinje cell EPSPs were insensitive to any of the inhibitors used in the present study and were, therefore, unlikely to have been mediated through the NO/cGMP/PKG cascade, PKC, mGluRs, or via adenosine-A1 receptors. These effects were not observed after postsynaptic injection of dipyridamole, suggesting a presynaptic or extracellular site of action.

Dipyridamole and Zaprinast produced almost identical longterm effects on epsp slopes and the epsp recovery time constant, $\tau_{2}$. These effects were significantly blocked by inhibition of NOS or PKG. Although dipyridamole can additionally inhibit cAMPspecific PDE type IV, PDE II (cGMP stimulated), and to a lesser extent PDE I (calcium-calmodulin stimulated; Lugnier et al., 1992) at the concentrations used here, the similarity of its effect to that of Zaprinast, a more specific inhibitor of cGMP-specific (type V) phosphodiesterases, lends support to the proposal that the long-term effects of these compounds on EPSP slope and duration were mediated primarily through an increase in cGMP concentration.

Direct injection of dipyridamole in the dendrites of Purkinje cells also led to a depression of EPSP slopes to a level indistinguishable from that of extracellular application. KT5823 was equally effective whether applied extracellularly or injected/dialyzed postsynaptically, and introduction of the PKC inhibitor 
A

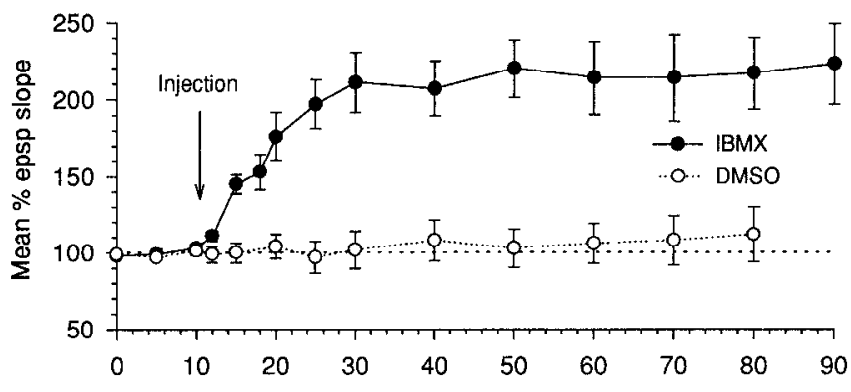

B

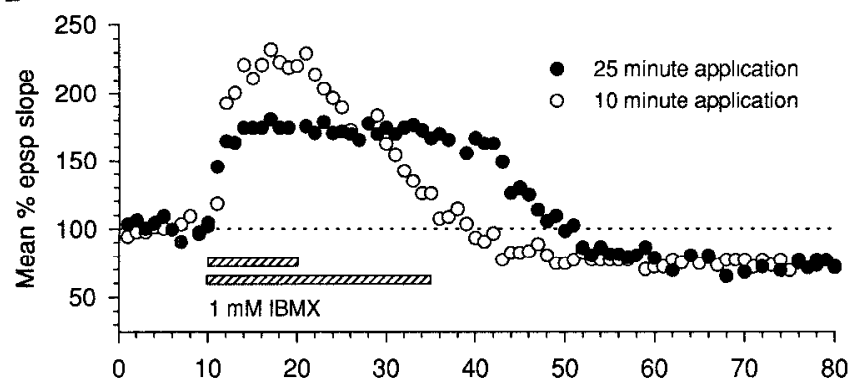

C

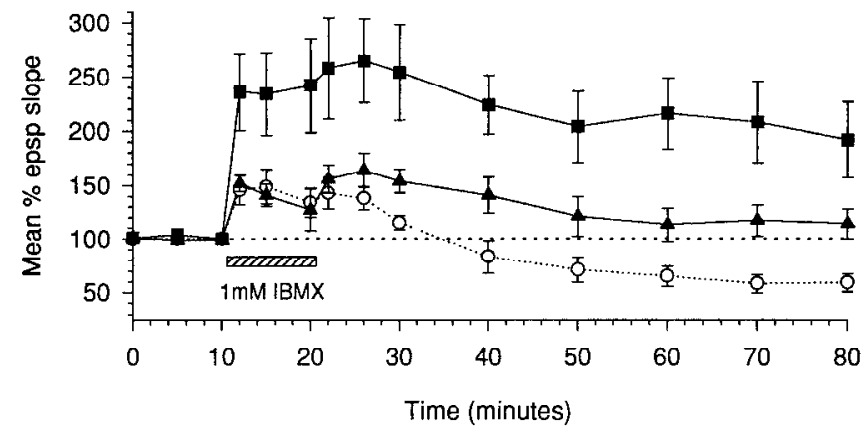

..... ACSF alone $\rightarrow$ KT5823 in bath $\quad$ - Chelerythrine in pipette

Figure 10. Mechanism of action of IBMX. A, Inclusion of $1 \mathrm{mM}$ IBMX, dissolved in DMSO, to the recording pipette led to a clear potentiation of $\mathrm{PF}$ responses $(n=4$; means and SEs shown). A single injection after a 10 min control period caused a rapid increase in PF-EPSP slope that was maintained for the duration of the recordings (solid circles). Similar injections of the vehicle DMSO had no effect $(n=5$; open circles). $B$, Extending the duration of bath application of $1 \mathrm{~mm}$ IBMX led to a prolongation of the duration of potentiation proportional to the extended period of application. $C$, The effects of bath application of $1 \mathrm{mM} \mathrm{IBMX}$ are compared with those obtained with $90 \mathrm{nM}$ KT5823 included in the perfusate (solid squares; $n=4$ ) and with $10 \mu \mathrm{M}$ chelerythrine in the recording pipette (solid triangles; $n=5$ ).

chelerythrine into Purkinje cells also prevented PDE-inhibitor mediated LTD, a finding consistent with previous data, illustrating that both PKG and PKC must be active for LTD induction (Hartell, 1994a,b) (see also Linden and Connor, 1991). Thus, the long-term actions of dipyridamole and Zaprinast on EPSP slopes are mediated postsynaptically by mechanisms involving the NO/cGMP/PKG cadscade and, in addition, PKC. Although these data do not shed any additional light on the controversy surrounding the site and the mechanism of NO production, these data provide strong evidence that the target for NO is the Purkinje cell and that cGMP is an important endogenous intermediary in the process of LTD.

In addition to its effects on phosphodiesterases, dipyridamole has been reported to inhibit adenosine uptake (Van Belle, 1985), and in the hippocampus, Zaprinast transiently reduces synaptic transmission through a mechanism thought to involve presynaptic adenosine-A1 receptors but that is triggered by cGMP elevation (Broome et al., 1994). Here, blockade of adenosine-A1 receptors increased baseline levels of PF-EPSP slopes, indicating a tonic level of adenosine receptor activation. It did not, however, prevent Zaprinast-induced depression of EPSP slopes, indicating that adenosine receptor activity is not important for the expression of LTD. Interestingly, however, DPCPX did block the long-term decrease in $\tau_{2}$. Takahashi et al. (1995) recently showed that adenosine strongly increased the rate of decay of EPSCs and argued that this may reflect a more rapid uptake or diffusion of glutamate away from the synapse as a consequence of reduced transmitter release. If such an effect could also be seen as a reduction in EPSP duration, it is possible that these presynaptic effects could contribute to the depression observed after bath application of Zaprinast or dipyridamole. Such an action is, nevertheless, clearly not essential for the induction and expression of LTD because the overall level of depression of EPSP slopes induced by Zaprinast in the presence of DPCPX was indistinguishable from that in naive slices. From these data, it is possible to infer that an increase of cGMP in the Purkinje cell not only leads to a reduction in EPSP slope but may additionally trigger some factor that acts retrogradely to affect transmitter release through an adenosine related mechanism. Recent evidence suggests that cGMP can be transported outside cells (Luo et al., 1994) and it can also have direct extracellular effects at high concentrations (Linden et al., 1995). It is conceivable, therefore, that cGMP itself could be the retrograde messenger.

\section{Actions of IBMX}

In contrast to the effects of dipyridamole and Zaprinast, bath applications of the nonspecific phosphodiesterase inhibitor IBMX led to a dramatic potentiation of PF-EPSP slopes. This potentiation was dependent on the continued presence of IBMX and declined rapidly after washout to reveal an underlying depression of synaptic efficacy. This LTD is likely to have been mediated by cGMP for two reasons. First, the extent of depression was dose dependent, which is consistent with the finding that basal levels of cGMP are more strongly elevated in the presence of $1 \mathrm{mM}$ IBMX compared with $0.1 \mathrm{~mm}$ (Okada, 1992). Second, this late phase of depression was completely prevented by the addition of the PKG inhibitor KT5823. In the absence of PKG activity, the initial IBMX-induced potentiation was considerable pronounced, presumably because it was unchecked by any concurrent cGMP/PKG mediated depression, and remained potentiated, even after washout of IBMX.

Sabatini and Regeher (1995) reported that IBMX, which can also inhibit adenosine receptors, enhances presynaptic calcium influx and reduces the threshold of PF activation. Although these presynaptic mechanisms are likely to contribute to the potentiation observed in the present report, dendritic injections of IBMX were also found to induce potentiation, suggesting some additional postsynaptic effect. Other possible mechanisms of modulation could involve the formation of other cyclic nucleotides such as cAMP, particularly because a possible metabolic target, protein kinase A, is present in Purkinje cells (Caretta et al., 1991). However, bath application of 8-Br-cAMP was, more often than not, found to induce depression of PF responses (N. Hartell, unpublished observations).

Injection of the PKC antagonist chelerythrine failed to influence the initial IBMX mediated potentiation but it did prevent the induction of subsequent LTD. Unlike the effect of KT5823, how- 
ever, no long-term potentiation was observed. From these data, it is possible to speculate that the level of activity of PKG might influence the direction of change in synaptic efficacy but PKC activity is required for a such change to occur.

\section{Is phosphodiesterase-induced LTD equivalent to conventional LTD?}

Conventional LTD, induced by pairing PF and CF inputs to a Purkinje cell, characteristically requires repetitive activity of the PF pathway at an optimum rate of $1 \mathrm{~Hz}$ (Karachot et al., 1995). Halting PF stimulation during dipyridamole application and for variable periods during washout led to a significant, but not complete, reduction in the level of depression of PF responses. A significantly greater level of depression was observed in inputs activated at $1 \mathrm{~Hz}$ than in separate inputs to the same cell stimulated at $0.2 \mathrm{~Hz}$, indicating that this depression was, at least partly, associative. The level of PF stimulation is therefore important in determining the degree of depression.

It has been shown by several groups that blockade of mGluRs prevents LTD induction (Alba et al., 1994; Conquet et al., 1994; Hartell, 1994a) and that this receptor subtype is likely to be activated at the higher rates of PF stimulation necessary for LTD (Batchelar and Garthwaite, 1993). A requirement for mGluR activation for phosphodiesterase-induced LTD was also observed in the present study confirming previous data showing that mGluRs must be active for both synaptic and cGMP-mediated LTD to take place (Hartell, 1994a). Together, these findings may well explain the greater degree of depression observed in the presence of Zaprinast at stimulation rates of $1 \mathrm{~Hz}$ compared with $0.2 \mathrm{~Hz}$ where mGluR activation is likely to be more.

$\Lambda$ recent report has shown that a combination of cell depolarization (replacing the $\mathrm{CF}$ input) and release of caged $\mathrm{NO}$ is sufficient to induce LTD, suggesting that NO and presumably cGMP completely replace the need for PF stimulation in LTD (Lev Ram et al., 1995). Given that a combination of calcium influx, AMPA receptor, and $\mathrm{mGluR}$ activation are the minimum requirements for LTD, these data suggest that $\mathrm{NO} / \mathrm{cGMP}$ replace both AMPA and mGluR activation. This is hard to reconcile with the present data and that of a previous report (Hartell, 1994a), which indicate that PDE-inhibitor and CGMP-induced LTD are prevented by inhibition of mGluRs. Furthermore, although LTD has been shown to be input specific (Ekerot and Kano, 1985 and also see Linden, 1994), neither calcium elevation through CF stimulation or depolarization nor NO, which is highly diffusible, would be expected to maintain site specificity. Input specificity would be maintained, however, if activation of mGluRs is an additional requirement for LTD as suggested here.

The present results are in agreement with an increasing number of studies in slice preparations that support a role for NO/cGMP/ PKG in cerebellar LTD (Crepel and Jaillard, 1990; Shibuki and Okada, 1991, 1992; Ito and Karachot, 1992; Daniel et al., 1993, 1995; Hartell, 1994a,b; Lev-Ram et al., 1995; but Glaum ct al., 1992). In cultured preparations, the NO/cGMP/PKG pathway does not appear to be important for the expression of LTD (Linden and Connor, 1992; Linden et al., 1995). Because LTD in culture is expressed and mediated postsynaptically it was suggested that in slices NO might exert its effects presynaptically on the PF terminal (see Linden et al., 1995). The present results, together with previous work (Daniel et al., 1993; Hartell, 1994a,b) indicate that this is unlikely. Because Purkinje cells themselves lack NOS, the source of NO is likely to be a different cell type, and several candidates have been proposed (see Linden, 1994, for a review). Recently, it has been shown that two distinct forms of LTD exist in slices, only one of which involves the NO/cGMP/ PKG cascade and that the PF is a likely source of NO (Hartell, in press). The lack of involvement of NO/cGMP in LTD in cultured preparations presumably, therefore, represents a fundamental difference between these two systems caused by the reduced level of synaptic input to the Purkinje cell.

Synaptically and cGMP/PDE-inhibitor-induced forms of LTD were found to be mutually occlusive, indicating that these two pathways for LTD induction have the same end result, presumably through phosphorylation mediated downregulation or desensitization of AMPA receptors. Because cGMP was not artificially introduced in this study, these results support the possibility that cGMP is an endogenous mediator of LTD. Clearly, the level of phosphodiesterase activity in Purkinje cells is normally sufficiently high to limit cGMP accumulation, and therefore cellular modulation of phosphodiesterase activity may provide an additional mechanism by which cells regulate synaptic efficacy. Given the basal rate of cGMP production evident from this study, a change in either the rate of synthesis or rate of break down of cGMP may well be equally effective in inducing LTD.

\section{REFERENCES}

Alba A, Kano M, Chen C, Stanton ME, Fox GD, Herrup K, Zwingman TA, Tonegawa $S$ (1994) Deficient cerebellar long-term depression and impaired motor learning in mGluR1 mutant mice. Cell 79:377-388.

Ariano MA, Lewicki JA, Brandwein HJ, Murad F (1982) Immunohistochemical localization of guanylate cyclase within neurons of rat brain. Proc Natl Acad Sci USA 79:1316-1320.

Balaban CD, Billingsley ML, Kincaid RL (1989) Evidence for a transsynaptic regulation of calmodulin-dependent cyclic nucleotide phosphodiesterase in cerebellar Purkinje cells. J Neurosci 9:2374-2381.

Batchelar AM, Garthwaite J (1993) Novel synaptic potentials in cerebellar Purkinje cells: probable mediation by metabotropic glutamate receptors. Neuropharmacology 32:11-20.

Beavo JA, Reifsnyder DH (1990) Primary sequence of cyclic nucleotide phosphodiesterase isozymes and the design of selective inhibitors. Trends Pharmacol Sci 11:150-155.

Boulton CL, Irving AJ, Southam E, Potier B, Garthwaite J, Collingridge GL (1994) The nitric oxide-cyclic GMP pathway and synaptic depression in rat hippocampal slices. Eur J Neurosci 6:1528-1535.

Broome MR, Collingridge GL, Irving AJ (1994) Activation of the NOcGMP signalling pathway depresses hippocampal synaptic transmission through an adenosine receptor-dependent mechanism. Neuropharmacology 33:11:1511-1513.

Bruns RF, Fergus JH, Badger FW, Bristol JA, Santay LA, Hartman JD, Hays ST, Hwang CC (1987) Binding of the A1-selective adenosine antagonist 8-cyclopentyl-1,3-dipropylxanthine to rat membranes. Naunyn Schmiedebergs Arch Pharmacol 335:59-63.

Carella A, Cevolani D, Luppino G, Matelli M, Tirindelli R (1991) Characterization and regional distribution of a class of synapses with highly concentrated cAMP binding sites in the rat brain. Eur $\mathbf{J}$ Neurosci $3: 669-687$.

Conquet $\mathrm{F}$, Bahir $\mathrm{ZI}$, Davies $\mathrm{CH}$, Daniel H, Ferraguti F, Bordi F, Franz-Bacon K, Reggiani A, Matarese V, Conde F, Collingridge GL, Crepel F (1994) Motor deficit and impairment of synaptic plasticity in mice lacking mGluR1. Nature 372:237-243.

Crepel F, Krupa M (1988) Activation of protein kinase $C$ induces a long-term depression of glutamate sensitivity of cerebellar Purkinje cells. An in vitro study. Brain Res 458:397-401.

Crepel F, Jaillard D (1990) Protein kinases, nitric oxide and long-term depression of synapses in the cerebellum. NeuroReport 1:133-136.

Daniel H, Hemart N Jaillard D, Crepel F (1993) Long-term depression requires nitric oxide and guanosine $3^{\prime}, 5^{\prime}$ cyclic monophosphate production in rat cerebellar Purkinje cells. Eur J Neurosci 5:1079-1082.

Denk W, Sugimori M, Llinas R (1985) Two types of calcium response limited to single spines in cerebellar Purkinje cells. Proc Natl Acad Sci USA 92:8279-8282.

Eilers J, Augustine GJ, Konnerth A (1995) Subthreshold synaptic Calcium signalling in fine dendrites and spines of cerebellar Purkinje neurons. Nature 373:155-158. 
Ekerot C-F, Kano M (1985) Long-term depression of parallel fiber synapses following stimulation of climbing fibers. Brain Res 342:357-360.

Glaum SR, Slater NT, Rossi DJ, Miller RJ (1992) Role of metabotropic glutamate (ACPD) receptors at the parallel fiber-Purkinje cell synapse. J Neurophysiol 68:4:1453-1462.

Hartell NA (1994a) Induction of cerebellar long term depression requires activation of glutamate metabotropic receptors. NeuroReport 5:913-916.

Hartell NA (1994b) cGMP acts within cerebellar Purkinje cells to produce long term depression via mechanisms involving PKC and PKG. NeuroReport 5:833-836.

Hartell NA (1996) Strong stimulation of parallel fibers produces localized calcium transicnts and a form of LTD which spreads to distant synapses. Neuron, in press.

Hemart N, Daniel H, Jaillard D, Crepel F (1995) Receptors and second messengers involved in long-term depression in rat cerebellar slices in vitro: a reappraisal. Eur J Neurosci 7:45-53.

Herbert JM, Augereau JM, Glaye J, Maffrand JP (1990) Chelerythrine is a potent and specific inhibitor of protein kinase $C$. Biochem Biophys Res Commun 172:993-999.

Ito M, Karachot L (1990) Receptor subtypes involved in, and time course of, the long-term desensitization of glutamate receptors in cerebellar Purkinje cells. Neurosci Res 8:303-307.

Ito M, Karachot L (1992) Protein kinases and phosphatase inhibitors mediating long-term desensitization of glutamate receptors in cerebellar Purkinje cells. Neurosci Res 14:27-38.

Ito M, Sakurai M, Tongroach P (1982) Climbing fiber induced depression of both mossy fiber responsiveness and glutamate sensitivity of cerebellar Purkinje cells. J Physiol (Lond) 324:113-134.

Kano M, Rexhausen U, Dreessen J, Konnerth A (1992) Synaptic excitation produces a long-lasting rebound potentiation of inhibitory synaptic signals in cerebellar Purkinje cells. Nature 356:601-604.

Karachot L, Kado RT, Ito M (1995) Stimulus parameters for induction of long-term depression in in vitro rat Purkinje cells. Neurosci Res 21:161-168

Kincaid RL, Balaban CD, Billingsley ML (1987) Differential localization of calmodulin-dependent enzymes in rat brain: evidence for selective expression of cyclic nucleotide phosphodiesterase. Proc Natl Acad Sci USA 84:1118-1122.

Knöpfel T, Vranescic C, Staub VC, Gähwiler BH (1990) Climbing fiber responses in olivo-cerebellar slice cultures. II. Dynamics of cytosolic calcium in Purkinje cells. Eur J Neurosci 3:343-348.

Konnerth A, Dreessen J, Augustine GJ (1992) Brief dendritic calcium signals initiate long-lasting synaptic depression in cerebellar Purkinje cells. Proc Natl Acad Sci USA 89:7051-7055.

Konnerth A, Llano I, Armstrong CM (1990) Synaptic currents in cerebellar Purkinje cells. Proc Natl Acad Sci USA 87:2662-2665.

Lev-Ram V, Makings LR, Keitz PF, Kao JPY, Tsien RY (1995) Longterm depression in cerebellar Purkinje neurons results from coincidence of nitric oxide and depolarization-induced $\mathrm{Ca}^{2+}$ transients. Neuron $15: 407-415$

Linden DJ (1994) Input-specific induction of cerebellar long-term depression does not require presynaptic alteration. Learn Memory 1:121-128.
Linden DJ, Connor JA (1991) Participation of post-synaptic PKC in cerebellar long-term depression in culture. Science 254:1656-1659.

Linden DJ, Connor JA (1992) Long-term depression of glutamate currents in cultured cerebellar Purkinje neurons does not require nitric oxide signalling. Eur J Neurosci 4:10-15.

Linden DJ, Dickinson MH Smeyne M, Connor JA (1991) A long-term depression of AMPA currents in cultured cerebellar Purkinje neurons. Neuron 7:81-89.

Linden DJ, Smeyne M, Connor JA (1993) Induction of cerebellar longterm depression in culture requires postsynaptic action of sodium ions. Neuron 11:1093-110.

Linden DJ, Dawson TM, Dawson VL (1995) An evaluation of the nitric oxide/cGMP/cGMP-dependent protein kinase cascade in the induction of cerebellar long-term depression in culture. J Neurosci 15:5098-5105.

Lohmann SM, Walter U, Miller PE, Greengard P, Camilli PD (1981) Immunohistochemical localization of cyclic-GMP-dependent protein kinase in the mammalian brain. Proc Natl Acad Sci USA 78:653-657.

I.ugnier C, Gauthier C, I e Rec A, Soustre H (1992) Cyclic nuclentide phosphodiesterases form frog atrial fibers: isolation and drug sensitivities. Am J Physiol 262:H654-H660.

Luo D, Lcung E, Vincent SR (1994) Nitric oxide-dependent efflux of cGMP in rat cerebellar cortex: an in vivo microdialysis study. J Neurosci 14:263-271.

Mayer B, Klatt P, Bohme E, Schmidt K (1992) Regulation of neuronal nitric oxide and cyclic GMP formation by $\mathrm{Ca}^{2+}$. J Neurochem 59:6:2024-2029.

Nairn AC, Hemmings HC, Greengard P (1985) Protein kinases in the brain. Annu Rev Biochem 54:931-976.

Nakanishi S (1989) K-252-derivatives-K252a, K252b, KT5720, KT5962, KT5823. Seitaino-Kagaku 40:364-365 (in Japanese).

Okada D (1992) Two pathways of cyclic GMP production through glutamate receptor-mediated nitric oxide synthesis. J Neurochem 59:1203-1210.

Ross WN, Werman R (1987) Mapping of calcium transients in the dendrites of Purkinje cells from the guinea pig cerebellum in vitro. J Physiol (Lond) 389:319-336.

Sabatini BL, Regeher WG (1995) Detecting changes in calcium influx which contribute to synaptic modulation in mammalian brain slice. Neuropharmacology 34:1453-1467.

Sakurai M (1990) Calcium is an intracellular mediator of the climbing fiber induction of cerebellar long-term depression. Proc Natl Acad Sci USA 87:3383-3385.

Shibuki K, Okada D (1991) Endogenous nitric oxide release required for long-tern synaptic depression in the cerebellum. Nature 349:326-328.

Shigemoto R, Abe T, Nomura S, Nakanishi S, Hirano T (1994) Antibodies inactivating mGluR1 metabotropic glutamate receptor block long-term depression in cultured Purkinje cells. Neuron 12:1245-1255.

Southam E, Morris R, Garthwaite J (1992) Sources and targets of nitric oxide in rat cerebellum. Neurosci Lett 137:241-244.

Takahashi M, Kovalchuk Y, Attwell D (1995) Pre- and postsynaptic determinants of EPSC waveform at cerebellar climbing fiber and parallel fiber to Purkinje cell synapses. J Neurosci 15:5693-5702.

Van Belle H (1985) Myocardial purines during ischaemia, reperfusion and pharmacological protection. Mol Pharmacol 8:615-630. 